\title{
Penggunaan macam mulsa dan pola jarak tanam terhadap pertumbuhan dan produksi Pakchoy (Brassica rapa chinensis 1.)
}

\section{(Using types of mulch and the plant spacing patterns on growth and production of pakchoy

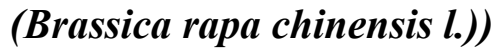

\author{
H. Irawati ${ }^{*}$, E. D. Purbajanti ${ }^{1}$, Sumarsono ${ }^{1}$,dan D. Fatchullah ${ }^{2}$ \\ Program Studi S-1 Agroekoteknologi \\ ${ }^{1}$ Fakultas Peternakan dan Pertanian, Universitas Diponegoro, Semarang \\ ${ }^{2}$ Balai Penelitian Tanaman Sayuran, Lembang \\ *)E-mail:heniirawati23@gmail.com
}

\begin{abstract}
Problems in the cultivation of plants pakchoy were caused by the influence of the physical environment such as climate, wind, temperature, the intensity of solar radiation, humidity, and soil. The research was aimed to know types of mulch and patterns of the plant spacing for optimizing growth and yield of pakchoy. This experiment was conducted in the experimental field of Margahayu, Balai Penelitian Tanaman Sayuran, Lembang on September-November 2016. The design of the research was randomized block design factorial with 9 treatment combinations and 3 replications. The first factor was "Types of Mulch": M0 (no mulch), M1 (black silver plastic mulch), and M2 (rice straw mulch). The second factor was The Plant Spacing Patterns": J0 (10x10 cm_triangle), J1 (20x20 cm_square), and J2 (30x30 cm hexagonal). Data was analyzed using analysis of variance (ANOVA) and continued by Duncan Multiple's Range Test (DMRT) at $\alpha=5 \%$. The result showed that the use of black silver plastic mulch and spacing pattern of $20 \times 20 \mathrm{~cm}$ (square) was a combination of the best treatment because it had the highest fresh weight of the canopy and the fresh weight of the roots, namely fresh weight of canopy $5,02 \mathrm{~kg}$ and weight of fresh roots $253,6 \mathrm{~g}$.
\end{abstract}

Keywords : pakchoy, mulching, productivity

\begin{abstract}
ABSTRAK
Permasalahan dalam budidaya tanaman pakchoy disebabkan oleh adanya pengaruh lingkungan fisik seperti iklim, angin, suhu, intensitas penyinaran matahari, kelembaban, serta tanah. Penelitian bertujuan untuk mengetahui jenis mulsa dan pola jarak tanam untuk meningkatkan pertumbuhan dan hasil tanaman pakchoy. Penelitian dilaksanakan pada bulan September-November 2016 di Kebun Percobaan Margahayu, Balai Penelitian Tanaman Sayuran, Lembang. Penelitian ini dilakukan dengan menggunakan percobaan faktorial $3 \times 3$ dan diulang sebanyak 3 kali. Faktor pertama adalah "Macam Mulsa", yaitu M0 (tanpa mulsa), M1 (mulsa plastik hitam perak), dan M2 (mulsa jerami padi). Faktor kedua adalah "Pola Jarak Tanam", yaitu J0 (10x10 cm_segitiga), J1 (20x20 cm_persegi), dan J2 (30x30 $\mathrm{cm}$ segi enam). Data dianalisis dengan menggunakan metode analisis of varians (ANOVA) dan dilanjutkan dengan uji wilayah berganda Duncan taraf signifikasi 5\%. Hasil penelitian ini menunjukkan bahwa penggunaan mulsa plastik hitam perak dan pola jarak tanam $20 \times 20 \mathrm{~cm}$ (persegi) merupakan kombinasi perlakuan terbaik karena memiliki berat segar tajuk dan berat segar akar paling tinggi apabila dibandingkan dengan kombinasi perlakuan yang lainnya, yaitu berat segar tajuk per petak sebesar 5,02 $\mathrm{kg}$ dan berat segar akar per petak 253,6 g.

Kata Kunci: pakchoy, mulsa, produktivitas
\end{abstract}




\section{PENDAHULUAN}

Pakchoy termasuk tanaman sayuran berumur pendek ( \pm 45 hari) yang termasuk dalam famili Brassicaceae serta memiliki kandungan gizi yang diperlukan tubuh. Kandungan betakaroten pada pakchoy dapat mencegah penyakit katarak, selain itu pakchoy juga mengandung protein, lemak nabati, karbohidrat, serat, sodium, vitamin A, vitamin $\mathrm{B}, \mathrm{Ca}, \mathrm{Mg}$, dan $\mathrm{Fe}$ (Perwtasari dkk., 2012). Pakchoy dapat ditanam di dataran rendah maupun dataran tinggi, akan tetapi pertumbuhannya lebih optimal apabila ditanam di dataran tinggi dengan cukup sinar matahari, aerasi baik (tidak tergenang air), serta $\mathrm{pH}$ tanah sekitar 5,5-6 (Edi dan Julistia, 2010).

Tanaman pakchoy apabila ditinjau dari aspek ekonomis dan bisnisnya layak untuk dikembangkan dan diusahakan di Indonesia guna untuk memenuhi permintaan konsumen yang semakin lama semakin meningkat serta adanya peluang pasar baik didalam maupun diluar negeri. Kelayakan pengembangan budidaya sawi ditunjukkan oleh adanya keunggulan kondisi wilayah tropis Indonesia yang sangat cocok untuk komoditas tersebut, disamping itu umur panen pakchoy relatif pendek yaitu 40-50 hari setelah tanam dan hasilnya pun dapat memberikan keuntungan yang memadai. Menurut Badan Pusat Statistik dan Direktorat Jenderal Hortikultura (2015) produksi sawi di Indonesia pada tahun 2011-2015 yaitu 580,969 ton, 594,911 ton, 635,728 ton, 602,468 ton, dan 600,188 ton dengan laju pertumbuhan sebesar $-0,38 \%$. Hal tersebut menunjukkan bahwa terdapat kecenderungan produksi yang tidak stabil, bahkan penurunan produksi sawi yang signifikan terjadi pada tahun 2014 dan 2015 bila dibandingkan dengan produksi tahun 2013. Penurunan hasil tersebut disebabkan oleh adanya pengaruh lingkungan fisik seperti iklim, angin, suhu, intensitas penyinaran matahari, kelembaban, serta tanah. Oleh karena itu, upaya yang dapat dilakukan untuk mengatasi pengaruh lingkungan fisik yaitu dengan cara merekayasa lingkungan seperti memodifikasi iklim mikro diantaranya dapat dilakukan dengan menggunakan mulsa.

Mulsa merupakan setiap bahan yang dipakai untuk menutupi permukaan tanah yang berfungsi untuk menghindari kehilangan air melalui penguapan serta dapat menekan pertumbuhan gulma. Budidaya tanaman sayuran dengan menggunakan mulsa merupakan salah satu usaha perlindungan fisik tanaman untuk memanipulasi faktor cuaca yang tidak menguntungkan bagi perkembangan tanaman (Yudhistira dkk., 2014). Efek aplikasi mulsa ditentukan oleh jenis bahan mulsa. Bahan yang dapat digunakan sebagai mulsa yaitu sisa-sisa tanaman (seresah dan jerami) atau bahan plastik (Hamdani, 2009). Penggunaan mulsa dari bahan tanaman (jerami) dapat berguna sebagai pupuk apabila telah terurai didalam tanah setelah mengalami proses dekomposisi. Selain itu, mulsa ini memiliki efek menurunkan suhu tanah serta dapat menambah bahan organik tanah dalam rentan waktu tertentu. Penggunaan mulsa plastik terutama mulsa plastik hitam perak memiliki kelebihan yaitu dapat memantulkan sinar matahari, menaikkan suhu tanah, menjaga kelembaban tanah, dan menurunkan kelembaban di sekitar tanaman sehingga dapat menghambat munculnya penyakit yang disebabkan oleh bakteri (Kusuma dan Mimik, 2015).

Disamping penggunaan mulsa untuk memodifikasi lingkungan fisik, perlu diatur pula kepadatan populasi tanaman, karena hal tersebut dapat mempengaruhi hasil tanaman pakchoy. Pengaturan kepadatan populasi ada dua cara, yaitu dengan pengaturan jarak tanam dan pola jarak tanam. Pola jarak tanam merupakan salah satu faktor yang juga dapat mempengaruhi kualitas dan kuantitas tanaman. Pola jarak tanam perlu diperhatikan karena dapat mempengaruhi tingkat kompetisi antar tanaman dalam hal air, unsur hara, dan cahaya matahari. Berdasarkan hasil penelitian tentang bentuk tanam menunjukkan bahwa bentuk tanam segitiga memiliki kelebihan dibanding bentuk tanam tipe lainnya. Salah satu kelebihannya yaitu, apabila dengan menggunakan jarak tanam yang sama, maka bentuk tanam tipe segitiga memiliki lebih banyak populasi setiap bedengnya dibanding bentuk tanam tipe segiempat (Hatta, 2011). Jarak tanam yang optimum akan memberikan pertumbuhan yang baik sehingga tanaman dapat memanfaatkan lebih banyak cahaya matahari dan unsur hara. Sebaliknya, jarak tanam yang terlalu rapat akan mengakibatkan terjadinya kompetisi antar tanaman yakni dalam hal air, unsur hara, dan cahaya matahari. Akibatnya, pertumbuhan tanaman terhambat dan hasil 
tanaman rendah (Sohel dkk., 2009).

Tujuan dari penelitian ini yaitu untuk mengetahui jenis mulsa dan pola jarak tanam yang terbaik untuk mendapatkan pertumbuhan dan produksi yang maksimal pada tanaman pakchoy yang dibudidayakan.

\section{METODE PENELITIAN}

Penelitian dilaksanakan pada bulan September - November 2016 di Kebun Percobaan Margahayu, Balai Penelitian Tanaman Sayuran (BALITSA) Lembang, yang terletak di Jl. Tangkuban Perahu, No. 517, Desa Cikole, Kecamatan Lembang, Kabupaten Bandung Barat, Provinsi Jawa Barat dengan ketinggian tempat 1250 mdpl. Peralatan yang digunakan adalah semat mulsa, cangkul, ember, gembor, kaleng, meteran, penggaris, pisau, thermometer udara, thermometer tanah, timbangan digital, timbangan (kapasitas $100 \mathrm{~kg}$ ), timbangan analitik, kantong plastik, spektrofotometer, Leaf Area Meter, jerami padi, dan mulsa plastik hitam perak. Bahan yang digunakan dalam penelitian yaitu urea $(\mathrm{N})$, SP36 $(\mathrm{P}), \mathrm{KCl}(\mathrm{K})$, pupuk kandang sapi, benih pakchoy varietas "Flamingo". Penelitian dilakukan dengan menggunakan percobaan faktorial $3 \times 3$ dan diulang sebanyak 3 kali. Faktor pertama adalah "Macam Mulsa", yaitu M0 (tanpa mulsa), M1 (mulsa plastik hitam perak), dan M2 (mulsa jerami padi). Faktor kedua adalah "Pola Jarak Tanam", yaitu J0 (10x10 cm_segitiga), J1 (20x20 cm_persegi), dan J2 (30x30 cm_segienam).

Pelaksanaan penelitian dimulai dengan persemaian dan pengolahan tanah, kemudian dilakukan pembuatan petak percobaan dengan ukuran $1,5 \mathrm{~m}$ x $1 \mathrm{~m}$ sebanyak 27 petak, jarak antar bedengan yaitu $50 \mathrm{~cm}$. Tanah diberi pupuk kandang sapi dengan dosis $1,5 \mathrm{~kg}$ per bedeng, lalu lahan dibiarkan selama 7 hari sebelum tanam. Bedengan ditutup dengan menggunakan mulsa plastik hitam perak (sesuai perlakuan), sedangkan mulsa jerami padi diaplikasikan setelah bibit pakchoy ditanam ke lahan. Setiap lubang tanam ditanami satu bibit dengan jarak tanam sesuai dengan taraf percobaan, sehingga pada perlakuan pola jarak tanam $10 \times 10 \mathrm{~cm}$ _segitiga terdapat 77 tanaman, 20x20 cm_persegi diperoleh 35 tanaman, dan 30x30 cm_segi enam diperoleh 12 tanaman. Pemeliharaan tanaman, meliputi pemupukan tahap kedua dengan menggunakan pupuk Urea (30 g/petak), $\mathrm{KCl}$ (7,5 g/petak), dan SP36 (15 g/petak). Penyulaman, dilakukan dengan cara mengganti bibit muda yang rusak atau menunjukkan gejala pertumbuhan yang kurang baik. Penyiraman, dilakukan pada sore hari dan dilakukan apabila dalam satu hari tidak turun hujan. Penyiangan gulma, dilakukan dengan cara mencabut gulma yang tumbuh disekitar tanaman pakchoy. Pengendalian hama dan penyakit pada tanaman pakchoy dilakukan dengan cara menyemprotkan insektisida berbahan aktif Permetrin/Profenofos, metaldehida/saponin, serta pestisida berbahan aktif Asam Oksolinik/Asilbenzolar-S-Metil+Mankozeb.

Panen dan pasca panen, pemanenan pakchoy dilakukan dengan cara mencabut seluruh bagian tanaman. Pakchoy yang telah dipanen, lalu dicuci dibawah air mengalir hingga bersih, setelah itu dilakukan pemisahan antara akar dengan pangkal batangnya dengan menggunakan pisau, lalu pakchoy disusun didalam keranjang.

Parameter yang diamati adalah tinggi tajuk, jumlah daun, lebar tajuk tanaman, indeks luas daun, kandungan khlorofil, berat segar tajuk per petak, dan berat segar akar per petak. Data hasil penelitian diolah dengan menggunakan metode analisis of varians (ANOVA) dan apabila terdapat pengaruh nyata maka dilanjutkan dengan uji wilayah berganda Duncan taraf signifikasi 5\%.

\section{HASIL DAN PEMBAHASAN}

\section{Tinggi Tajuk, Jumlah Daun, dan Lebar Tajuk}

Hasil analisis ragam menunjukkan bahwa tidak terdapat interaksi perlakuan macam mulsa dan pola jarak tanam terhadap tinggi tajuk, jumlah daun dan lebar tajuk, tetapi terdapat pengaruh nyata $(p<0,05)$ perlakuan macam mulsa terhadap tinggi tajuk, serta terdapat pula pengaruh nyata $(\mathrm{p}<0,05)$ perlakuan pola jarak tanam terhadap jumlah daun dan lebat tajuk tanaman pakchoy. Data pengaruh macam mulsa dan pola jarak tanam terhadap parameter tinggi tajuk, jumlah daun, dan lebar tajuk tanaman pakchoy dapat dilihat pada Tabel 1.

Mulsa plastik hitam perak sangat efektif dalam mengendalikan gulma, karena rumputrumput liar di bawah mulsa plastik tidak 
Tabel 1. Pengaruh Perlakuan Macam Mulsa dan Pola Jarak Tanam Terhadap Tinggi Tajuk, Jumlah Daun, dan Lebar Tajuk Tanaman Pakchoy

\begin{tabular}{lccc}
\hline \multicolumn{1}{c}{ Perlakuan } & Tinggi Tajuk $(\mathrm{cm})$ & $\begin{array}{c}\text { Jumlah Daun } \\
\text { (Helai) }\end{array}$ & $\begin{array}{c}\text { Lebar Tajuk } \\
(\mathrm{cm})\end{array}$ \\
\hline Mulsa (M) & $15,68 \mathrm{~b}$ & & \\
M0 (Tanpa Mulsa) & $17,98 \mathrm{a}$ & 5,11 & 18,27 \\
M1 (Mulsa Plastik Hitam Perak) & $15,98 \mathrm{~b}$ & 5,34 & 18,44 \\
M2 (Mulsa Jerami) & & 5,17 & 18,42 \\
\hline Pola Jarak Tanam (J) & 16,57 & & \\
J0 (10x10 cm_Segitiga) & 16,25 & $4,66 \mathrm{c}$ & $16,02 \mathrm{c}$ \\
J1 (20x20 cm_Persegi) & 16,82 & $5,72 \mathrm{a}$ & $21,53 \mathrm{a}$ \\
J2 (30x30 cm_Segienam) & - & $5,23 \mathrm{~b}$ & $17,57 \mathrm{~b}$ \\
\hline Interaksi & - & - \\
\hline
\end{tabular}

Keterangan : Superskrip yang berbeda pada kolom perlakuan menunjukkan berbeda nyata $(\mathrm{p}<0,05)$.

mendapatkan cahaya matahari untuk berfotosintesis. Apabila perkecambahan dan pertumbuhan gulma terhambat, maka pertumbuhan dan perkembangan tanaman pokok akan lebih optimal. Penggunaan mulsa warna hitam perak memiliki respon yang terbaik terhadap tinggi tanaman. Hal ini disebabkan karena warna hitam pada bagian bawah dapat menyebabkan perkecambahan maupun pertumbuhan gulma terhambat, sedangkan warna perak pada bagian atas mempunyai manfaat yaitu memantulkan sinar matahari yang berdampak pada proses fotosintesis. Seluruh sisi daun secara merata akan terkena sinar matahari, sehingga proses fotosintesis dapat berlangsung pada kedua sisi daun.

Apabila dilihat dari perlakuan pola jarak tanamnya, diduga pada perlakuan pola jarak tanam $20 \times 20 \mathrm{~cm}$ (Persegi) tanaman pakchoy sudah dapat tumbuh mencapai pertumbuhan yang optimum pada tinggi tanaman, jumlah daun, dan lebar tajuk tanaman, sehingga pada pola jarak tanam ini seluruh faktor fisiologis yang mempengaruhi pertumbuhan tanaman tidak terganggu. Sedangkan pada perlakuan jarak tanam 10x10 cm memiliki nilai lebih rendah yang disebabkan karena adanya kompetisi tanaman dalam mendapatkan sumberdaya untuk mendukung pertumbuhannya. Mawazin (2008) menyatakan bahwa jarak tanam akan mempengaruhi efektivitas penyerapan unsur hara oleh tanaman. Semakin rapat jarak tanam semakin banyak populasi per satuan luas, sehingga persaingan hara antar tanaman semakin ketat, akibatnya pertumbuhan tanaman akan terganggu. Berdasarkan hasil dari penelitian Purnama dkk. (2013) bahwa pengaruh yang optimal diperoleh pada perlakuan jarak tanam $20 \times 20 \mathrm{~cm}$, tetapi tidak berbeda nyata jika dibandingkan dengan perlakuan jarak tanam $30 \times 30 \mathrm{~cm}$. Perlakuan jarak tanam memang tidak memberikan pengaruh nyata terhadap pertambahan tinggi tanaman sawi. Namun, pengaturan jarak tanam yang tepat dapat berpengaruh dalam meningkatkan jumlah daun.

\section{Indeks Luas Daun dan Kandungan Khlorofil Daun}

Hasil analisis ragam menunjukkan bahwa tidak terdapat interaksi perlakuan macam mulsa dan pola jarak tanam terhadap indeks luas daun dan kandungan khlorofil daun, tidak terdapat pengaruh nyata perlakuan macam mulsa terhadap indeks luas daun dan kandungan khlorofil daun, tetapi terdapat pengaruh nyata $(p<0,05)$ perlakuan pola jarak tanam terhadap indeks luas daun dan kandungan khlorofil daun tanaman pakchoy. Data pengaruh macam mulsa dan pola jarak tanam terhadap parameter indeks luas daun dan kandungan khlorofil daun tanaman pakchoy dapat dilihat pada Tabel 2.

Indeks luas daun nyata lebih besar pada populasi dengan perlakuan jarak tanam 20x20 $\mathrm{cm}$ persegi dibandingkan pada populasi renggang 
Tabel 2. Pengaruh Perlakuan Macam Mulsa dan Pola Jarak Tanam Terhadap Indeks Luas Daun dan Kandungan Khlorofil Daun

\begin{tabular}{lcc}
\hline \multicolumn{1}{c}{ Perlakuan } & Indeks Luas Daun & Kandungan Khlorofil Daun \\
\hline Mulsa (M) & & \\
M0 (Tanpa Mulsa) & 4,41 & 20,31 \\
M1 (Mulsa Plastik Hitam Perak) & 5,07 & 20,44 \\
M2 (Mulsa Jerami) & 4,06 & 21,81 \\
\hline Pola Jarak Tanam (J) & & \\
J0 (10x10 cm_Segitiga) & $4,47 \mathrm{ab}$ & $19,53 \mathrm{~b}$ \\
J1 (20x20 cm_Persegi) & $5,43 \mathrm{a}$ & $19,74 \mathrm{~b}$ \\
J2 (30x30 cm_Segienam) & $3,63 \mathrm{~b}$ & $23,29 \mathrm{a}$ \\
\hline Interaksi & - & -
\end{tabular}

Keterangan : Superskrip yang berbeda pada kolom perlakuan menunjukkan berbeda nyata $(\mathrm{p}<0,05)$.

(30x30 cm_segienam), akan tetapi perlakuan pola jarak tanam 20x20 (persegi) tidak memiliki perbedaan yang nyata dengan pola jarak tanam $10 \times 10 \mathrm{~cm}$ (segitiga). Hal ini disebabkan karena pada perlakuan jarak tanam 20x20 cm dan 10x10 $\mathrm{cm}$ menghasilkan populasi tanaman dalam per petaknya cukup tinggi. Tanaman pakchoy pada perlakuan $20 \times 20 \mathrm{~cm}$ (persegi) diduga sudah dapat tumbuh mencapai pertumbuhan optimumnya pada indeks luas daun, radiasi matahari yang diteruskan dari daun-daun bagian atas masih bisa ditangkap oleh daun-daun dibawahnya. Amalia dkk. (2009) menyatakan bahwa indeks luas daun erat kaitannya dengan populasi tanaman, semakin tinggi populasi tanaman per satuan luas berakibat pada peningkatan indeks luas daun. Indeks luas daun yang tinggi menunjukkan bahwa radiasi matahari yang diteruskan dari daun-daun bagian atas masih bisa ditangkap oleh daun-daun dibawahnya.

Penggunaan pola jarak tanam 30x30 cm (Segienam) memiliki rerata khlorofil daun yang nyata lebih tinggi dibanding dengan pola jarak tanam 10x10 cm (Segitiga) dan 20x20 cm (Persegi), sedangkan perlakuan pola jarak tanam $10 \times 10 \mathrm{~cm}$ (Segitiga) memiliki rerata kandungan khlorofil daun yang tidak berbeda dengan pola jarak tanam 20x20 cm (Persegi). Penggunaan jarak tanam yang renggang menyebabkan tanaman dapat berkembang dengan baik, cahaya yang dapat dimanfaatkan tanaman untuk berfotosintesis lebih besar. Amalia dkk. (2009) bahwa semakin banyak kandungan khlorofil maka kemungkinan terjadinya proses fotosintesis akan berjalan lebih cepat sehingga fotosintat yang dihasilkan pun lebih tinggi. Fotosintat digunakan untuk memenuhi kebutuhan tanaman, pertumbuhan serta sebagai cadangan makanan.

\section{Berat Segar Tajuk per Petak dan Berat Segar Akar per Petak}

Hasil analisis ragam menunjukkan bahwa terdapat pengaruh interaksi nyata $(p<0,05)$ perlakuan macam mulsa dan pola jarak tanam terhadap berat segar tajuk per petak dan berat segar akar per petak, terdapat pengaruh nyata $(p<0,05)$ perlakuan macam mulsa terhadap berat segar tajuk per petak dan berat segar akar per petak, serta terdapat pengaruh nyata $(p<0,05)$ perlakuan pola jarak tanam terhadap berat segar tajuk per petak dan berat segar akar per petak. Data pengaruh macam mulsa dan pola jarak tanam terhadap parameter berat segar tajuk dan berat segar akar tanaman pakchoy per petak dapat dilihat pada Tabel 3.

Tabel 3 menunjukkan bahwa berdasarkan rerata total perlakuan, pada perlakuan mulsa plastik hitam perak dengan pola jarak tanam 20x20 cm (persegi) memiliki berat segar tajuk per petak dan berat segar akar per petak paling tinggi dibandingkan dengan kombinasi perlakuan yang lainnya. Berat segar tajuk dan berat segar akar dengan penggunaan mulsa plastik hitam perak lebih baik apabila dibandingkan dengan kontrol (tanpa mulsa) dan mulsa jerami padi. Jika dilihat 
Tabel 3. Pengaruh Perlakuan Macam Mulsa dan Pola Jarak Tanam Terhadap Berat Segar Tajuk dan Berat Segar Akar Tanaman Pakchoy per Petak

\begin{tabular}{lcc}
\hline \multicolumn{1}{c}{ Perlakuan } & $\begin{array}{c}\text { Berat Segar Tajuk } \\
(\mathrm{kg} / \text { petak})\end{array}$ & $\begin{array}{c}\text { Berat Segar Akar } \\
(\mathrm{g} / \text { petak })\end{array}$ \\
\hline Mulsa (M) & & \\
M0 (Tanpa Mulsa) & $3,05 \mathrm{~b}$ & $143,3 \mathrm{ab}$ \\
M1 (Mulsa Plastik Hitam Perak) & $4,13 \mathrm{a}$ & $178,8 \mathrm{a}$ \\
M2 (Mulsa Jerami) & $2,99 \mathrm{~b}$ & $150,8 \mathrm{~b}$ \\
\hline Pola Jarak Tanam (J) & & \\
J0 (10x10 cm_Segitiga) & $3,89 \mathrm{a}$ & $212,2 \mathrm{a}$ \\
J1 (20x20 cm_Persegi) & $4,26 \mathrm{a}$ & $212,5 \mathrm{a}$ \\
J2 (30x30 cm_Segienam) & $2,02 \mathrm{~b}$ & $48,2 \mathrm{~b}$ \\
\hline Interaksi & & \\
Tanpa mulsa*10x10 cm_segitiga & $3,87 \mathrm{~b}$ & $237,1 \mathrm{a}$ \\
Tanpa Mulsa*20x20 cm_persegi & $4,14 \mathrm{~b}$ & $167,3 \mathrm{~b}$ \\
Tanpa Mulsa*30x30 cm_segienam & $1,14 \mathrm{~d}$ & $25,4 \mathrm{c}$ \\
MPHP*10x10 cm_segitiga & $4,23 \mathrm{~b}$ & $208,2 \mathrm{ab}$ \\
MPHP*20x20 cm_persegi & $5,02 \mathrm{a}$ & $253,6 \mathrm{a}$ \\
MPHP*30x10 3m_segienam & $3,14 \mathrm{c}$ & $74,7 \mathrm{c}$ \\
Mulsa jerami*10x10 cm_segitiga & $3,57 \mathrm{bc}$ & $191,4 \mathrm{ab}$ \\
Mulsa jerami*20x20 cm_persegi & $3,61 \mathrm{bc}$ & $216,7 \mathrm{ab}$ \\
Mulsa jerami*30x30 cm_segienam & $1,77 \mathrm{~d}$ & $44,3 \mathrm{c}$ \\
\hline
\end{tabular}

Keterangan : $\quad$ Superskrip yang berbeda pada kolom perlakuan menunjukkan berbeda nyata $(\mathrm{p}<0,05)$.

berdasarkan pengaruh pola jarak tanam, perlakuan pola jarak tanam 20x20 cm (persegi) memiliki berat segar tajuk dan berat segar akar paling tinggi apabila dibandingkan dengan kedua perlakuan yang lainnya, tetapi tidak berbeda nyata dengan perlakuan pola jarak tanam 10x10 cm (segitiga).

Hal tersebut diduga bahwa pada perlakuan pola jarak tanam $20 \times 20 \mathrm{~cm}$ (segienam), tanaman pakchoy memiliki rambut akar yang lebih banyak dan panjang sehingga akan membuat tanaman mampu menyerap air dan unsur hara lebih banyak. Menurut Purnama dkk. (2013) menyatakan bahwa dengan parakaran yang banyak hal tersebut juga dapat berpengaruh pada diameter batang tanaman pakchoy. Semakin besar diameter tanaman pakchoy, maka menandakan tanaman pakchoy memiliki banyak cadangan makanan yang nantinya akan berpengaruh pada hasil berat segar tajuk. Samiati dkk. (2012) bahwa pemberian mulsa dapat memberi pengaruh terhadap kelembaban tanah sehingga tercipta kondisi yang optimal untuk pertumbuhan tanaman. Apabila faktor lingkungan sesuai untuk pertumbuhan tanaman, maka fotosintat yang dihasilkan juga meningkat sehingga alokasi biomassa ke bagian yang dipanen juga relatif besar.

\section{KESIMPULAN}

Perlakuan macam mulsa dan pola jarak tanam mampu memberikan interaksi yang baik di lapangan terhadap produksi pakchoy. Penggunaan mulsa plastik hitam perak dan pola jarak tanam $20 \times 20 \mathrm{~cm}$ (persegi) merupakan kombinasi perlakuan terbaik karena memiliki berat segar tajuk dan berat segar akar paling tinggi apabila dibandingkan dengan kombinasi perlakuan yang lainnya, yaitu berat segar tajuk per petak sebesar $5,02 \mathrm{~kg}$ dan berat segar akar per petak 253,6 g.

\section{UCAPAN TERIMAKASIH}

Terimakasih disampaikan kepada Balai Penelitian Tanaman Sayuran (BALITSA), Lembang, Bandung, Jawa Barat yang telah memfasilitasi dalam penelitian. 


\section{DAFTAR PUSTAKA}

Amalia, T. S., D. Purnomo dan F. Fahrudin. 2009. Penggunaan ekstrak teh dan pupuk kascing pada budidaya caisim (Brassica juncea L.). J. Ilmu Tanah dan Agroklimatologi. 6(2): 6168.

Badan Pusat Statistik dan Direktorat Jenderal Hortikultura. 2015. Produksi Sayuran di Indonesia. Diakses tanggal 19 April 2017.

Edi, S. dan J. Bobihoe. 2010. Budidaya Tanaman Sayuran. Balai Pengkajian Teknologi Pertanian Jambi, Balai Besar Pengkajian dan Pengembangan Pertanian, Kementrian Pertanian.

Hamdani, J. S. 2009. Pengaruh jenis mulsa terhadap pertumbuhan dan hasil tiga kultivar kentang (Solanum tuberosum L.) yang ditanam di dataran medium. J. Agron Indonesia. 37(1): 14-20.

Hatta, M. 2011. Pengaruh tipe jarak tanam terhadap anakan, komponen hasil, dan hasil dua varietas padi pada metode SRI. J. Floratek. 6(2): 104-113.

Kusuma, A. H. dan M. U. Zuhro. 2015. Pengaruh varietas dan ketebalan mulsa jerami padi pada pertumbuhan dan hasil tanaman tomat (Lycopersicum esculentum Mill.). J. Agrotechbiz. 2(1): 1-10.
Mawazin dan H. Suhaendi. 2008. Pengaruh jarak tanam terhadap pertumbuhan diameter Shorea parvifolia Dyer. J. Penelitian Hutan dan Konservasi. 5(4): 381-388.

Perwtasari, B., M. Tripatmasari dan C. Wasonowati. 2012. Pengaruh media tanam dan nutrisi terhadap pertumbuhan dan hasil tanaman pakchoy (Brassica rapa L.) dengan sistem hidroponik. J. Agrovigor. 5(1): 14-25.

Purnama, R. H., S. J. Santoso dan S. Hardiatmi. 2013. Pengaruh dosis pupuk kompos enceng gondok dan jarak tanam terhadap pertumbuhan dan hasil tanaman sawi (Brassica juncea L.). J. Inovasi Pertanian. 12(2): 95-107.

Samiati., A. Bahrun dan L. A. Safuan. 2012. Pengaruh takaran mulsa terhadap pertumbuhan dan produksi sawi (Brassica juncea L.). J. Agronomi. 2(2): 1-7.

Sohel, M.A.T., M. A. B. Siddique and M. Asaduzzaman. 2009. Varietal performance of transplant aman rice under different hill densities. Bangladesh J. Agril Res. 34(1): 3339.

Yudhistira, G., M. Roviq dan T. Wardiyanti. 2014. Pertumbuhan dan produktivitas sawi pakchoy (Brassica rapa L.) pada umur transplanting dan pemberian mulsa organik. J. Produksi Tanaman. 2(1): 41-49. 